\title{
PENDAMPINGAN DAN PENGEMBANGAN LITERASI UNTUK SUPORTER SEPAKBOLA MELALUI JURNALISME SEPAKBOLA
}

\author{
${ }^{1}$ Fajar Junaedi, ${ }^{2}$ Filosa Gita Sukmono \\ Program Studi Ilmu Komunikasi, Universitas Muhammadiyah Yogyakarta \\ e-mail : ${ }^{1}$ fajarjun@umy.ac.id, ${ }^{2}$ filosa@umy.ac.id
}

\section{RINGKASAN}

Sepakbola dan jurnalisme adalah dua ranah yang saling terkait erat. Berita olahraga sepakbola menjadi sajian utama di berbagai media cetak, elektronik maupun daring. Suporter sepakbola secara umum adalah audiens aktif yang secara intens mengkonsumsi berita olahraga. Dalam konteks literasi media, hal ini keberadaan suporter sepakbola sebagai audiens aktif merupakan potensi untuk pengembangan literasi media. Literasi media yang akan dikembangkan dalam pengabdian ini adalah literasi media dalam proses produksi media yaitu jurnalisme sepakbola. Suporter sepakbola yang secara umum berasal dari kaum muda yang memiliki potensi untuk ditingkatkan kapasitas kompetensinya dalam hal jurnalisme sepakbola. Solusinya adalah melakukan pendampingan dan pengembangan literasi media melalui kegiatan jurnalisme sepakbola. Kegiatan pengabdian ini melibatkan Fandom Indonesia sebagai mitra. Aktivitas kegiatan yang dilakukan dalam program pengabdian masyarakat ini adalah dengan pelatihan, workshop dan pendampingan penulisan jurnalisme sepakbola. Ada dua puluh lima peserta yang mengikuti aktivitas kegiatan ini. Hasil kegitan berupa artikel, yang secara umum temanya adalah tentang sepakbola lokal, disunting oleh mitra. Artikel yang telah disunting kemudian dikompilasi menjadi satu naskah buku yang diberi judul Merawat Sepakbola Indonesia. Buku berhasil dicetak sebanyak dua ratus eksemplar, dan dijual melalui jejaring yang dimiliki mitra, serta melibatkan peserta sebagai reseller. Dengan demikian, program ini telah berhasil meningkatkan literasi sepakbola di kalangan suporter, dan menumbuhkan jejaring kewirausahaan suporter melalui penerbitan dan distribusi penjualan buku.

Kata kunci : literasi, jurnalisme, penulisan, suporter sepakbola

\section{ABSTRACT}

Football and journalism are two domains that are closely interrelated. Football sports news developed in various media platform, such as printed, electronic and online media. Football supporters, in general, are active audiences who are intensely consuming sports news. In the context of media literacy, the existence offootball supporters as an active audience is a potential for the development of media literacy. The media literacy that be developed in this program is media literacy in the process of media production, namely football journalism writing. Football supporters generally come from young people who have the potential to increase their competence in terms of football journalism, but they have lack access for developing their competence. The solution is to provide assistance and development of media literacy through football journalism activities. This service activity involves Indonesian Fandom as a partner. Activities carried out in this community service program are training, workshops and mentoring for writing football journalism. 
There were twenty-five participants who participated in this activity. The results of the activity in the form of articles, which in general the theme is about local football, edited by partners. Articles that have been edited are then compiled into one text book entitled Merawat Sepakbola Indonesia (Caring for Indonesian Football). The book was successfully printed as many as two hundred copies, and sold through networks owned by partners, and involved workshop participants as resellers. Thus, this program has succeeded in increasing football literacy among supporters, and fostering entrepreneurial networks of supporters through the publishing and distribution of book sales.

Keywords: literacy, journalism, writing, football supporters

\section{PENDAHULUAN}

Suporter sepakbola adalah kelompok masyarakat yang memberikan dukungan kepada klub sepakbola tertentu. Mereka memberikan dukungan dengan datang ke stadion saat klubnya bertanding, menyaksikan siaran televisi dan streaming pertandingan sepakbola, membaca berita tentang klub yang mereka dukung dan membeli produk merchandise. Secara umum, suporter sepakbola didominasi oleh kaum muda.

Di Yogyakarta, ada beberapa komunitas suporter sepakbola yaitu Brajamusti dan The Maident yang merupakan komunitas pendukung klub sepakbola PSIM Yogyakarta, Slemania dan Brigata Curva Sud (BCS) yang memberikan dukungan kepada PSS Sleman, serta Paserbumi dan Curva Nord Famiglia (CNF) yang memberikan dukungannya kepada Persiba Bantul. Fenomena sosial serupa juga dijumpai di berbagai kota lain, dengan nama komunitas suporter sepakbola yang beragam. Secara keseluruhan , mereka memiliki fanatisme yang tinggi dalam mendukung klub sepakbola. Fanatisme yang tinggi di kalangan suporter sepakbola yang tergabung dalam beragam komunitas ini merupakan potensi yang harus dikelola dengan baik.

Persoalan yang muncul dari pengelolaan komunitas suporter sepakbola yang tidak baik adalah munculnya konflik. Konflik yang terjadi di kalangan suporter sepakbola bisa mengarah kepada konflik fisik, seperti bentrokan, yang menyebabkan korban jiwa. Sayangnya, hal-hal yang negatif seperti inilah yang sering dilekatkan dengan suporter sepakbola. Suporter sepakbola mendapatkan stigma buruk dari masyarakat sebagai kelompok kaum muda yang identik dengan kekerasan. Pemberitaan media massa yang acapkali membingkai kerusuhan suporter sepakbola sebagai ulah kaum muda, semakin menguatkan stigma negatif yang disematkan kepada kaum muda suporter sepakbola.

Media sosial juga memiliki peran signifikan. Di era media sosial saat ini, konflik yang terjadi di antara suporter sepakbola umumnya dimulai dari provokasi yang terjadi di media sosial. Kaum muda suporter sepakbola secara umum adalah pengguna media sosial yang secara aktif terlibat interaksi dengan media. Rendahnya literasi media menyebabkan konflik menjadi membesar.Media sosial, alih-alih digunakan untuk meredam konflik, justru digunakan untuk menguatkan sentimen antarkelompok suporter sepakbola. Sebagai akibatnya, konflik menjadi semakin meluas. Meskipun demikian, juga harus disadari bahwa tidak semua suporter sepakbola terjebak dalam konflik. Ada kaum muda suporter sepakbola yang secara aktif terlibat dalam literasi media melalui penulisan tentang sepakbola di berbagai media, terutama media daring.

Untuk mengatasi persoalan konflik antarkaum muda suporter sepakbola di Yogyakarta ini adalah dengan memberikan penguatan kapasitas literasi media di kalangan suporter sepakbola. Dalam konteks literasi media, elemen-elemen literasi media menurut Art Silverblatt (1995), diantaranya: (1) kesadaran akan pengaruh media terhadap individu dan sosial; (2) pemahaman akan proses komunikasi massa; (3) pengembangan strategi untuk menganalisis dan mendiskusikan pesan media; (4) kesadaran bahwa isi media adalah teks yang menggambarkan kebudayaan dan diri kita sendiri pada saat ini; dan (5) mengembangkan kesenangan, pemahaman, dan penghargaan terhadap isi media (Silverbalt dalam Gumilar, Adiprasetio dan Maharani, 2017:38). James

Warta LPM, Vol. 22, No. 2, September 2019 
Potter (2008: 19) menyebutkan bahwa literasi media adalah seperangkat perspektif yang secara aktif mendorong kita untuk menafsirkan pesan media yang kita terima (a set of perspectives that we actively use to expose ourselves to the media to interpret the meaning of the messages we encounter). Sedang pengertian yang disepakati dalam The National Leadership Conference on Media Literacy adalah kemampuan untuk mengakses, menganalisis, mengevaluasi dan mengkomunikasikan pesan dalam beragam bentuk (the ability to access, analyze, evaluate dan communicate messages in a variatey of form) (Eadie, 2009: 560).

Dalam pengertian tersebut terkandung pemahaman adanya pengandaian sifat khalayak yang aktif (active audience) dalam berinteraksi dengan media. Relasi antara media dengan khalayak di jaman kontemporer sekarang ini bersifat niscaya. Artinya masyarakat modern tidak bisa melepaskan keberadaan dirinya dari media massa. Masyarakat dalam banyak urusan menggantungkan diri pada informasi media, baik itu media lama (cetak, radio, televisi) maupun media baru (internet).Kegiatan literasi media (Potter dalam Eadie, 2009: 561-564) akan terkait dengan tiga isu yang melingkupinya, yaitu apa yang dimaksudkan dengan media (what are media?), apa yang dimaksudkan dengan literasi (what do we mean by literacy?), dan apa tujuan dari literasi media (what should be the purpose of media literacy?).

Berdasarkan hal tersebut di atas, kegiatan pengabdian ini diarahkan pada pendampingan suporter sepakbola untuk mampu menghasilkan karya tulis yang berkaitan dengan sepakbola. Kolaborasi diantara suporter sepakbola yang berbeda latar belakang klub berimplikasi pada interaksi yang intens antarsuporter sepakbola. Dengan interaksi yang intens maka perbedaaan dukungan bisa dikelola secara baik dan positif. Hasil dari kegiatan literasi ini akan dibagikan kepada suporter sepakbola yang lain sebagai model kolaborasi antarsuporter sepakbola. Para suporter sepakbola yang mengikuti program ini diharapkan mendapatkan kompetensi jurnalisme sepakbola yang bisa menjadi bekal pengembangan skill mereka yang notabene adalah angkatan kerja produktif.
Mitra dalam pengabdian ini adalah Fandom Indonesia, yang biasa disebut dengan Fandom, yang beralamat di Sleman Yogyakarta. Fandom Indonesia awalnya bernama Football Fandom. Football Fandom secara aktif melakukan literasi sepakbola dengan publikasi majalah digital dan situs penulisan sepakbola (football writing). Setelah berganti nama menjadi Fandom Indonesia kegiatan literasi lebih banyak diarahkan dalam bentuk publikasi buku. Fandom pernah menerbitkan buku yang berisi tentang kajian sepakbola di Indonesia berjudul Sepakbola 2.0 (2016). Buku ini ditulis oleh penulis senior, bukan oleh para suporter yang berasal dari kaum muda.

Ini tentu saja merupakan potensi dari mitra yang bisa menjadi modal sosial dalam kegiatan pengabdian ini. Fandom juga memiliki relasi baik dengan berbagai kelompok suporter sepakbola di Yogyakarta yang disebutkan di awal.

Secara produksi dan manajemen usaha, Fandom memiliki lini media massa yang bernama Fandom dan distribusi buku yang dikelola dengan baik melalui Mojok Store. Potensi ini berhadapan dengan persoalan yaitu kurangnya artikel yang masuk dari para suporter sepakbola. Keduanya akan diselesaikan melakui kegiatan pengabdian ini. Solusi yang ditawarkan untuk menyelesaikan permasalahan mitra sebagi berikut :

a. Pelatihan tentang literasi media dan jurnalisme sepakbola yang diikuti oleh suporter sepakbola. Target luaran yang dihasilkan adalah artikel yang ditulis peserta yang bertema tentang sepakbola lokal. Jumlah artikel yang ditargetkan adalah 25 artikel.

b. Penyuntingan karya jurnalisme sepakbola dari suporter sepakbola yang mengikuti program pengabdian. Target luaran yang dihasilkan adalah dummy buku. Dummy buku dicetak sebanyak 2 eks.

c. Penerbitan buku berisi artikel dan reportase jurnalisme sepakbola. Target luaran yang dihasilkan adalah buku. Spesifikasi buku adalah sebagai berikut : book paper, ukuran 14x21, sampul art paper laminasi. Jumlah buku yang dicetak 200 eksemplar. 


\section{METODE}

Metode pelaksanaan kegiatan pengabdian masyarakat ini dilakukan sebagai berikut :

Pertama, menghubungi mitra pengabdian masyarakat dan mendiskusikan persoalan yang dihadapi dalam literasi untuk suporter sepakbola serta program kegiatan yang bisa dilakukan bersama untuk mengatasi persoalan yang dihadapi.

Kedua, membuat publikasi di media sosial tentang kegiatan yang dilakukan. Publikasi terutama dilakukan dengan memanfaatkan twitter dan instagram Fandom. Pemilihan kedua media sosial ini dilandasi pertimbangan bahwa keduanya merupakan media sosial yang memiliki segmen kaum muda. Berdasarkan pengamatan di media sosial, kedua platform aplikasi media sosial ini yang paling banyak mengundang keterlibatan kaum muda suporter sepakbola. Secara umum, publikasi yang dibuat adalah ketentuan tentang kegiatan dan undangan kepada kaum muda suporter sepakbola untuk mengikuti program dengan mengirimkan rancangan artikel. Alasan perlunya calon peserta mengirimkan rancangan artikel adalah agar bisa diketahui apakah peserta serius mengikuti program atau tidak. Sebagai indikator keseriusan adalah adanya rancangan artikel yang dikirimkan oleh calon peserta. Calon peserta yang mengirimkan rancangan artikel dan rancangan tersebut sesuai dengan tema dianggap sebagai calon peserta yang serius mengikuti program penulisan jurnalisme sepakbola.

Ketiga, penerimaan naskah dan seleksi terhadap rancangan karya tulis yang dikirimkan oleh peserta, yang dilanjutkan dengan pengumuman peserta yang terpilih mengikuti program pelatihan.

Keempat, pelatihan penulisan jurnalisme sepakbola yang dilakukan di Kafe Muda Mendunia. Kegiatan pelatihan, yang diikuti dengan workshop dan pendampingan kepada peserta ini dilaksanakan pada tanggal 13 Maret 2019. Jika ada peserta yang tidak mampu menyelesaikan artikel pada tanggal ini, pendampingan akan tetap dilakukan secara daring selama satu minggu.

Kelima, penyuntingan naskah peserta yang dilanjutkan dengan pembuatan dummy buku. Setelah dummy buku disusun, dilakukan penyelarasan aksara (proof reading) dan segera dilanjutkan dengan penerbitan buku.

\section{HASIL DAN PEMBAHASAN}

\section{A. Hasil}

Sejak awal penyusunan proposal, program pengabdian ini disusun bersama dengan mitra, sehingga secara keseluruhan berjalan dengan lancar. Saat penyusunan proposal bersama mitra, disepakati judul pengabdian ini adalah Pendampingan dan Pengembangan Literasi untuk Suporter Sepakbola Melalui Jurnalisme Sepakbola.

Publikasi kegiatan pengabdian dilakukan melalui media sosial, terutama dengan menggunakan akun twitter Fandom yang beralamat di akun @Fandom_ID. Akun twitter Fandom memiliki pengikut (follower) sebanyak 36.500. Jumlah yang sangat besar untuk segmentasi media sepakbola.

Publikasi yang dilakukan melalui akun twitter Fandom Indonesia berhasil viral di media sosial, dengan indikator adanya reply sebanyak 13, retweet sebanyak 119 dan like sebanyak 67. Statistik ini menunjukan bahwa publikasi yang dilakukan telah berhasil menjadi viral.

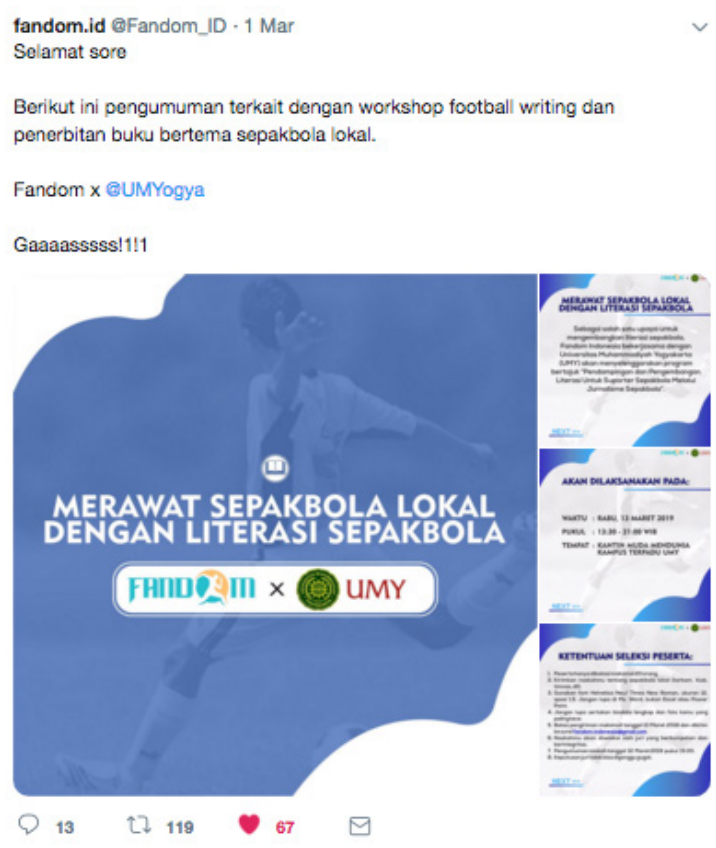

Gambar 1. Publikasi program kegiatan di akun twitter Fandom Indonesia.

Warta LPM, Vol. 22, No. 2, September 2019 
Setelah publikasi menjadi viral, tercatat ada 35 naskah yang dikirim oleh calon peserta. Seleksi naskah dilakukan bersama dengan melibatkan Dr. Fajar Junaedi dan Dr. Filosa Gita Sukmono dari Universitas Muhammadiyah Yogyakarta (UMY) dan Sirajudin Hasbi S.IP dan Moddie Alvianto MA, dari Fandom Indonesia. Seleksi dilakukan dengan mempertimbangkan kesesuaian draft artikel dengan tema penulisan sepakbola lokal.

Proses seleksi dilakukan selama satu hari dan akhirnya diputuskan terpilih 25 calon peserta. Pada awalnya target peserta adalah suporter sepakbola yang berasal dari Daerah Istimewa Yogyakarta saja, mengingat peserta dari luar propinsi ini harus mengeluarkan biaya transportasi untuk datang mengikuti kegiatan pelatihan. Meskipun mereka sebenarnya tidak perlu mengeluarkan biaya untuk mengikuti kegiatan pelatihannya, namun pertimbangan tentang biaya transportasi sempat muncul. Setelah diadakan diskusi dengan mitra dan mempertimbangkan keseriusan peserta untuk mengikuti kegiatan pelatihan, akhirnya peserta dari luar Yogyakarta tetap diterima dengan konsekuensi biaya transportasi menjadi tanggung jawab calon peserta.

Pada tanggal 13 Maret 2019 kegiatan pelatihan penulisan jurnalisme sepakbola dilakukan di Kafe Muda Mendunia. Acara pelatihan dimulai jam 13.00 sampai dengan 22.00 WIB. Jalannya pelatihan penulisan sepakbola bisa dideskripsikan sebagai berikut. Kegiatan pelatihan penulisan jurnalisme sepakbola dimulai dengan pembukaan dan perkenalan peserta oleh Sirajudin Hasbi, pimpinan redaksi Fandom Indonesia. Sirajudin Hasbi menjelaskan kepada peserta pelatihan tentang latar belakang kegiatan, tujuan kegiatan, target kegiatan dan alur pelatihan yang harus diikuti oleh peserta. Setelah penjelasan tentang alur pelatihan, peserta diberikan kesempatan untuk memperkenalkan diri. Perkenalan peserta meliputi nama, asal institusi dan rencana tema artikel yang akan ditulis. Perkenalan tema paper ini diperlukan agar semua peserta mengetahui keseluruhan rencangan tema dan bahkan judul dari masing-masing peserta, serta memungkinkan adanya kolaborasi antarpeserta dalam pencarian informasi yang berkaitan dengan tema yang dipilih.
Kegiatan pelatihan penulisan jurnalisme sepakbola dilanjutkan dengan sesi pemaparan tentang kondisi sepakbola Indonesia, terutama di daerah oleh pembicara utama (keynote speaker) Ir. Ahmad Syauqi Soeratno MM. Ahmad Syauqi Soeratno pernah menjabat sebagai manajer PSIM Yogyakarta dan direktur Badan Liga Amatir Indonesia. Ahmad Syauqi Soeratno menjelaskan tentang beragam persoalan yang ada dalam sepakbola Indonesia, meliputi tata kelola sepakbola secara nasional maupun di daerah, kesenjangan pemahaman tentang peraturan sepakbola di berbagai daerah, posisi suporter sepakbola, terutama kaum muda yang terdidik, dalam pengembangan sepakbola Indonesia dan perlunya literasi sepakbola. Selesai pemaparan dari Ahmad Syauqi Soeratno dilanjutkan dengan sesi tanya jawab.

Kegiatan pelatihan penulisan jurnalisme sepakbola kemudian dilanjutkan dengan sesi workshop, dengan mekanisme dan desain kegiatan workshop adalah sebagai berikut. Fasilitator membagi peserta dalam tigakelompok, yang masing-masing kelompok beranggotakan 6 sampai 8 orang. Dasar pertimbangan pembagian kelompok adalah tema yang ditulis oleh peserta. Kelompok pertama dengan fasilitator Sirajudin Hasbi, kelompok kedua dengan fasilitator Dr. Fajar Junaedi, dan kelompok ketiga dengan fasilitator Dr. Filosa Gita Sukmono. Fasilitator keempat adalah Moddie Alvianto yang bertugas untuk melayani kebutuhan workshop yang membutuhkan mobilitas, seperti penggandaan draft artikel, penyediaan akses sambungan listrik dan penyediaan alat tulis.

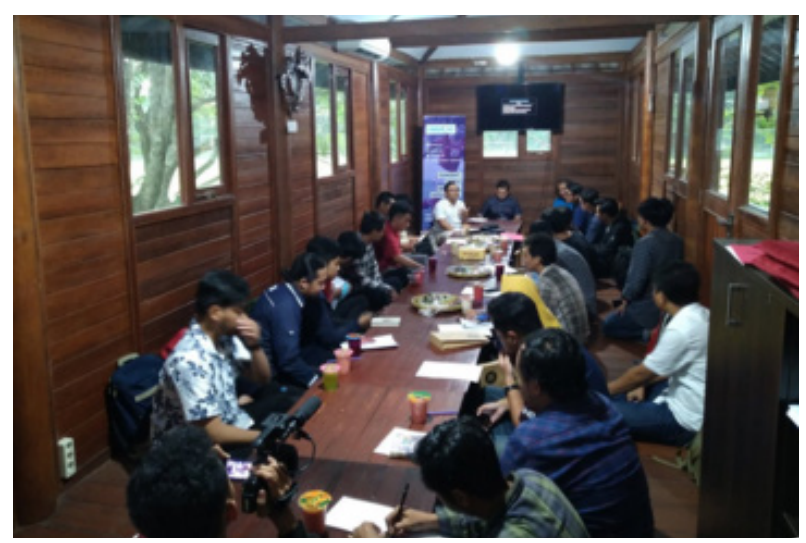

Gambar 2. Suasana pelatihan penulisan jurnalistik sepakbola di Kafe Muda Mendunia. 
Di setiap kelompok, fasilitator memberikan kesempatan kepada masing-masing peserta untuk menjelaskan rencana pengembangan artikel. Rencana pengembangan artikel yang disampaikan oleh peserta ditanggapi oleh fasilitator, dengan memberikan penekanan pada proses pencarian data sebagai sumber penulisan artikel, proses penulisan kreatif pengembangan artikel, dan penggunaan Bahasa Indonesia yang baku, baik dan benar. Fasilitator juga memberikan kesempatan kepada peserta lain untuk memberikan komentar, pertanyaan dan atau rekomendasi pengembangan artikel kepada peserta yang lain.

Setelah melalui proses diskusi yang difasilitasi oleh fasilitator, peserta diberikan kesempatan untuk menulis di laptop yang mereka bawa. Pada kegiatan pelatihan penulisan jurnalisme sepakbola, sejak awal peserta memang diminta untuk membawa laptop. Fasilitator di setiap kelompok mendampingi peserta yang sedang mengerjakan artikel yang mereka tulis. Jika ada pertanyaan dan persoalan yang dihadapi peserta, fasilitator pelatihan penulisan jurnalisme sepakbola langsung memberikan tanggapan dan solusi.

Di akhir sesi workshop pelatihan penulisan jurnalisme sepakbola, peserta mengumpulkan artikel yang mereka tulis selama mengikuti pelatihan. Bagi peserta yang belum berhasil menyelesaikan artikel, fasilitator memberikan kesempatan pendampingan secara daring. Peserta diminta untuk segera menyelesaikan artikel dengan batas waktu tujuh hari pasca workshop pelatihan penulisan jurnalisme sepakbola. Untuk memudahkan koordinasi, baik dengan peserta yang telah menyelesaikan artikelnya maupun yang belum menyelesaikan artikel, fasilitator membuat grup whatsapp. Anggota grup adalah seluruh peserta pelatihan penulisan jurnalisme sepakbola dan fasilitator. Grup ini sekaligus digunakan untuk memberikan pembaharuan (up date) proses penerbitan buku dan rilis buku. Tercatat ada dua puluh satu peserta yang berhasil menyelesaikan artikel dengan baik sesuai target dan panduan.

Seminggu setelah pelatihan penulisan jurnalisme sepakbola, tim editor mulai melakukan penyuntingan dan kompilasi naskah. Tim editor berasal dari Fandom Indonesia, yaitu Sirajudin Hasbi dan Moddie Alvianto. Proses penyuntingan dan kompilasi naskah membutuhkan waktu dua hari. Bersamaan dengan penyuntingan dan kompilasi naskah, sampul (cover) buku didesain oleh desainer Fandom Indonesia.

Naskah-naskah artikel yang terkompilasi dalam satu file draft naskah buku kemudian dimasukan ke percetakan untuk ditata letak (lay out). Pencetakan naskah dilakukan di percetakan Mata Padiyang berada di Mantrijeron, Yogyakarta. Setelah satu minggu naskah masuk ke percetakan, dummy buku diberikan oleh percetakan kepada Fandom Indonesia. Dummy buku yang diterima menjalani proses penyelarasan aksara. Tim penyeleras aksara berasal dari Universitas Muhammadiyah Yogyakarta, yaitu Dr. Fajar Junaedi dan Dr. Filosa Gita Sukmono. Pembagian tugas ini dimaksudkan agar naskah yang terbit benar-benar terjamin kualitas penulisannya. Terjaminnya kualitas artikel ditentukan oleh dua indikator. Indikator pertama adalah penulisan yang sesuai dengan tata bahasa Indonesia yang baik dan benar. Indikator yang kedua adalah isi dan substansi artikel yang sesuai dengan tema yang telah ditentukan sejak mula program pengabdian ini dirancang, yaitu bertema tentang sepakbola lokal. Selain kedua indikator tersebut, ada indikator tambahan yaitu tidak adanya plagiarisme dalam artikel yang dikirimkan oleh peserta.

Proses penyelarasan aksara pada dummy buku membutuhkan waktu satu hari. Dummy buku yang telah dikoreksi dan diselaraskan diserahkan kembali ke percetakan untuk poses naik cetak. Proses percetakan naskah membutuhkan waktu 5 hari, meliputi proses pembuatan master, pencetakan master buku, pencetakan sampul, penjilidan buku dan pengemasan buku dalam plastik pembungkus.

Setelah buku terbit, Fandom Indonesia melakukan publikasi di media sosial dan media massa tentang pemesanan buku melalui mekanisme pre order. Para penulis yang terlibat dalam program penulisan jurnalisme sepakbola dilibatkan sebagai reseller buku, dengan tujuan untuk meningkatkan kewirausahaan mitra dan para peserta.

Warta LPM, Vol. 22, No. 2, September 2019 
fandom.id @Fandom_ID · 11 jarn

Buku "Merawat Sepakbola Indonesia" segera terbit $\hat{\theta}, \hat{\theta}$ :

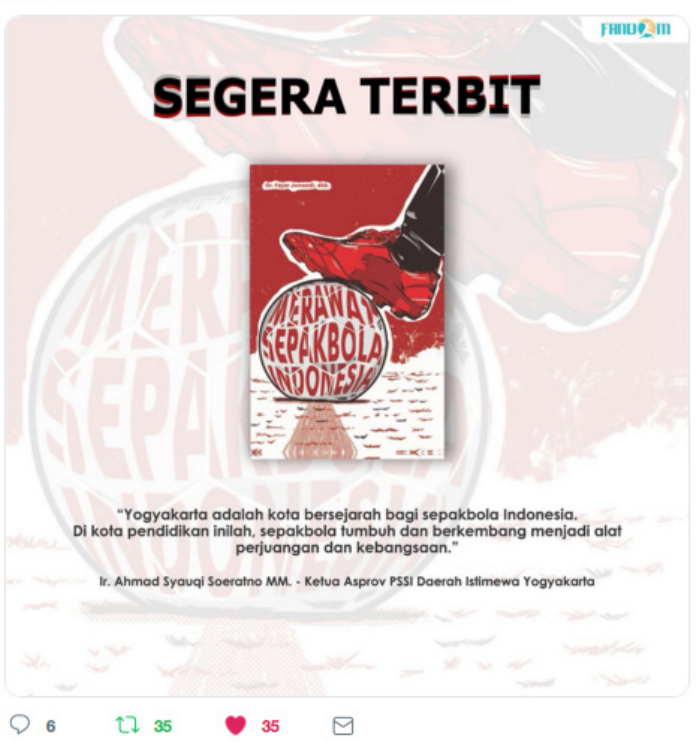

Gambar 3. Informasi tentang telah terbitnya buku Merawat Sepakbola Indonesia.

Informasi tentang terbitnya buku Merawat Sepakbola Indonesia diinformasikan di twitter Fandom pada tanggal 11 Juni 2019. Di media sosial, informasi tentang terbitnya buku Merawat Sepakbola Indonesia berhasil viral dengan ditandai adanya 6 reply, 35 retweet dan 35 like.

Sebagai puncak dari program program pengabdian masyarakat ini adalah peluncuran buku Merawat Sepakbola Indonesia yang dilakukan pada tanggal 2 Juli 2019 di Legend Kafe, Jl. Abubakar Ali, Yogyakarta. Acara peluncuran buku dihadiri oleh para suporter sepakbola yang penulis buku, yang telah berproses mulai dari pengiriman rancangan artikel, mengikuti pelatihan dan mengikuti pendampingan revisi penulisan. Selain para penulis, peluncuran buku juga mengundang ketua Asosiasi Provinsi (Asprov) Persatuan Sepakbola Seluruh Indonesia (PSSI) Daerah Istimewa Yogyakarta (DIY), Ahmad Syauqi Soeratno dan pengurus inti Asprov PSSI DIY. Undangan juga disebar ke kalangan wartawan dan media komunitas sepakbola di Yogyakarta.

Kegiatan pengabdian ini diberitakan di Tribun Jogja dalam sebuah berita berjudul Merawat Sepakbola Lokal Lewat Dunia Literasi. Berita yang pertama kali tayang tanggal 14 Maret 2019 bisa diakses di tautan http:// jogja.tribunnews.com/2019/03/14/merawatsepakbola-lokal-lewat-dunia-literasi.

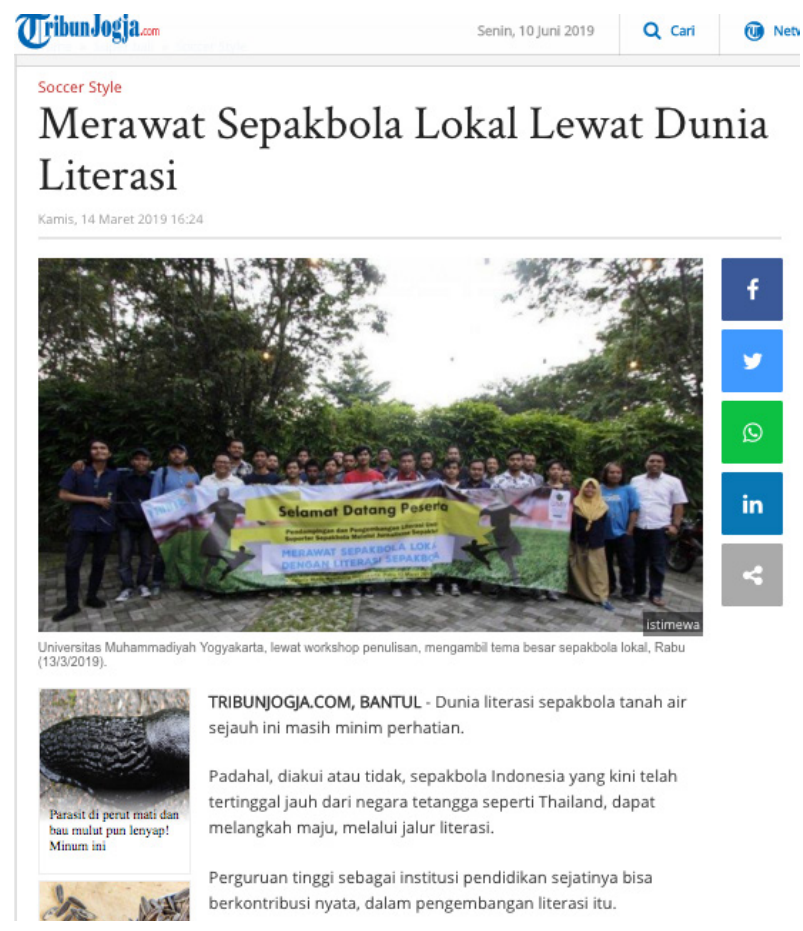

Gambar 4. Berita kegiatan pengabdian di Tribun Jogja.

Times Indonesia memberitakan kegiatan launching buku Merawat Sepakbola Indonesia melalui berita berjudul "Dosen UMY Gelar Kajian Literasi Bertema Sepakbola". Berita di Times Indonesia ini bisa dibaca di tautan berikut ini https://www.timesindonesia.co.id/ $\mathrm{read} / 219097 / 20190703 / 201800 /$ dosen-umygelar-kajian-literasi-bertema-sepak-bola/ .

\section{Dosen UMY Gelar Kajian Literasi Bertema Sepak Bola}
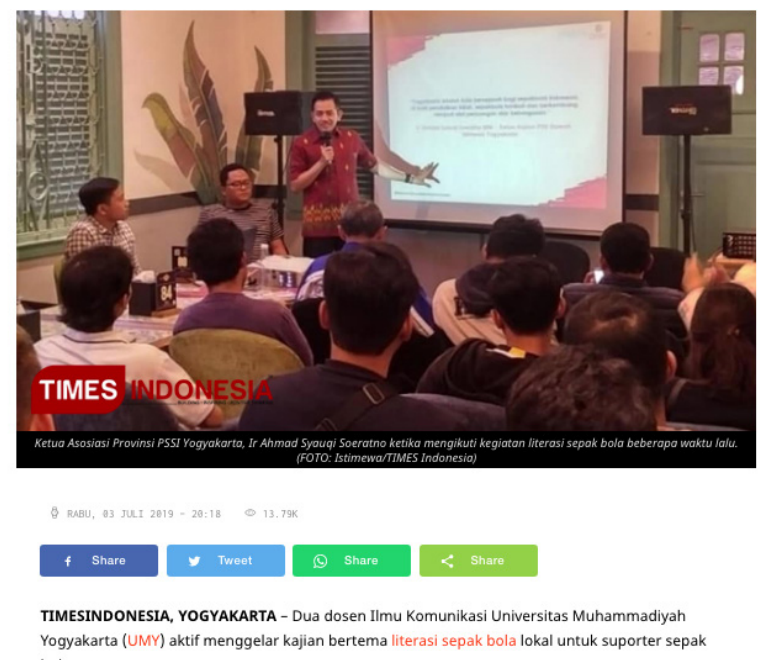
Yogya.

Gambar 6. Berita launching buku Merawat Sepakbola Indonesia di Times Indonesia. 
Pemberitaan tentang pengabdian ini, mulai dari saat pelatihan sampai dengan peluncuran buku luaran dari pengabdian masyarakat ini menunjukan bahwa program pengabdian masyarakat ini dibingkai secara positif oleh media massa.

\section{B. Pembahasan}

Program pengabdian masyarakat ini telah memberikan kemanfaatan kepada mitra dan peserta. Bagi mitra dan peserta, program pengabdian masyarakat ini memberikan kemanfaatan berupa meningkatnya literasi sepakbola melalui penulisan jurnalisme sepakbola. Suporter sepakbola yang selama ini diidentikan atau mendapat stigma negatif, karena terutama terjadinya kekerasan yang melibatkan suporter sepakbola, berhasil membuktikan diri mampu melakukan kegiatan positif dalam bentuk literasi.

Proses seleksi yang dilakukan sejak program pengabdian ini dijalankan telah berhasil mengeliminasi peserta yang motivasinya hanya ikut pelatihan penulisan saja. Dari awal memang program pengabdian ini ditujukan untuk menghasilkan luaran dalam bentuk buku yang berasal dari artikel karya peserta, bukan hanya sekadar pelatihan penulisan. Untuk mencapai hal ini, tim program pengabdian telah sejak awal merancang proses seleksi terhadap rancangan artikel yang dikirimkan oleh peserta.

Pertimbangan dalam proses seleksi didasarkan pada beberapa hal. Pertama, kesesuaian isi rancangan terhadap tema penulisan. Rancangan artikel yang diterima adalah rancangan artikel yang berisi tentang sepakbola Indonesia. Beberapa rancangan artikel terpaksa tidak diterima karena isinya tentang sepakbola luar negeri, terutama sepakbola Eropa. Hal ini sebenarnya bisa dimaklumi karena literatur dan pemberitaan tentang sepakbola luar negeri sangat banyak tersedia, berbeda dengan sepakbola Indonesia. Kedua, keseriusan calon peserta untuk mengikuti pelatihan. Calon peserta yang mengirimkan rancangan artikel yang berisi proyeksi artikel yang akan ditulis dianggap sebagai calon peserta yang serius mengikuti pelatihan.

Melalui proses yang panjang ini, manfaat yang diperoleh oleh peserta adalah mereka mampu memahami tentang bagaimana mekanisme dan proses penerbitan buku dari penulisan rancangan artikel, pengembangan artikel, penyuntingan artikel sampai dengan penerbitan buku. Manfaat yang bersifat hard skill ini berelasi dengan manfaat yang bersifat soft skill. Dalam kaitannya dengan manfaat soft skill peserta sebagai penulis atau jurnalis sepakbola yang memiliki etos kuat dalam penulisan.

Manfaat lanjutan dari program ini adalah para peserta yang telah memiliki kompetensi dalam penulisan sepakbola memiliki kemampuan untuk menulis artikel tentang sepakbola Indonesia, yang selanjutnya dikirimkan ke media massa. Pada saat pelatihan penulisan, fasilitator selalu memberikan motivasi kepada peserta agar tidak hanya menulis artikel melalui program pengabdian masyarakat ini saja, namun secara aktif tetap terus menulis dan mengirimkan artikel yang ditulis ke media massa, karena kemampuan menulis adalah kompetensi yang harus selalu diasah.

Buku Merawat Sepakbola Indonesia yang menjadi luaran dari program pengabdian masyarakat ini meningkatkan positioning para penulisnya saat mengirimkan artikel ke media massa. Para penulis yang mengirimkan artikel ke media massa bisa memberikan atribusi kepada diri mereka masing-masing dengan menuliskan diri sebagai "penulis buku Merawat Sepakbola Indonesia." Dengan atribusi seperti ini, redaktur media massa yang menjadi tujuan pengiriman artikel dari penulis yang telah menuliskan atribusi seperti ini, memberikan perhatian dan pertimbangan lebih. Bagi redaktur, penulis yang telah memiliki portofolio - dalam hal ini portofolio tersebut adalah buku Merawat Sepakbola Indonesia - lebih punya nilai lebih dibandingkan penulis yang tidak memiliki portofolio.

Manfaat lanjutan dari program pengabdian masyarakatiniadalah tumbuhnya kewirausahaan dalam industri kreatif penerbitan buku. Mitra dan peserta kegiatan menjual buku yang semua keuntungannya dimanfaatkan oleh mitra dan peserta. Peserta juga mengetahui proses kreatif penulisan dan penerbitan buku, sehingga diharapkan di masa selanjutnya, peserta dengan difasilitasi mitra bisa menerbitkan buku lagi. Dengan demikian keberlanjutan program literasi ini bisa terus berjalan.

Warta LPM, Vol. 22, No. 2, September 2019 
Tabel 1. Perbedaan Kondisi Sebelum dan Sesudah Kegiatan Pengabdian Masyarakat

\begin{tabular}{lll}
\hline \multicolumn{1}{c}{ Kegiatan } & \multicolumn{1}{c}{ Sebelum } & \multicolumn{1}{c}{ Sesudah } \\
\cline { 2 - 3 } $\begin{array}{l}\text { Pelatihan penulisan } \\
\text { jurnalisme sepakbola }\end{array}$ & $\begin{array}{l}\text { Peserta belum menulis artikel } \\
\text { untuk buku tentang sepakbola } \\
\text { lokal. }\end{array}$ & $\begin{array}{l}\text { Peserta mampu menulis artikel } \\
\text { untuk buku tentang sepakbola } \\
\text { lokal. }\end{array}$ \\
$\begin{array}{l}\text { Penerbitan buku sepakbola } \\
\text { tentang sepakbola lokal. }\end{array}$ & $\begin{array}{l}\text { Peserta belum pernah } \\
\text { menerbitkan buku tentang } \\
\text { sepakbola lokal. }\end{array}$ & $\begin{array}{l}\text { Peserta berhasil menerbitkan } \\
\text { buku tentang sepakbola lokal } \\
\text { dengan judul buku "Merawat }\end{array}$ \\
Peserta menjadi reseller & Peserta belum pernah menjadi \\
buku. & reseller buku karya mereka. & $\begin{array}{l}\text { Pepakbola Indonesia" } \\
\text { buku karya merekadi reseller }\end{array}$ \\
& & terobosan dalam pengembangan \\
& & $\begin{array}{l}\text { kewirausahaan di sektor } \\
\text { ekonomi kreatif. }\end{array}$ \\
\hline
\end{tabular}

Hambatan yang terjadi dalam program pengabdian ini adalah adanya peserta yang tidak mengumpulkan karya sampai batas akhir waktu, yaitu sejumlah empat orang. Sehingga dari dua puluh lima peserta yang mengikuti kegiatan, total artikel yang terkumpul adalah dua puluh satu. Tim editor sebenarnya telah berusaha menghubungi peserta yang belum menyelesaikan artikelnya, namun sampai batas akhir yang ditentukan, peserta tidak menyelesaikannya.

\section{KESIMPULAN}

Program pengabdian ini telah berhasil dilaksanakan dengan baik. Hal ini diindikasikan dengan tercapainya target, yaitu meningkatnya literasi sepakbola sebagaimana yang ditandai dengan terbitnya buku Merawat Sepakbola Indonesia yang ditulis oleh para peserta. Kerjasama yang baik dengan mitra telah menjadikan program pengabdian ini bisa mudah dijalankan.
Saran bagi program pengabdian sejenis di masa mendatang adalah melibatkan suporter di daerah, terutama yang media komunitas sepakbolanya belum berkembang. Hal ini ditujukan agar literasi sepakbola berkembang sampai ke daerah. Selain itu juga perlu ada pendampingan kepada pada peserta lebih intensif agar semua peserta yang mengikuti pelatihan bisa konsisten untuk terus menulis sampai buku terbit.

\section{PERSANTUNAN}

Program pengabdian masyarakat ini bisa terlaksana atas dukungan dari Dr. Gunawan Budiyanto (rektor Universitas Muhammadiyah Yogyakarta), Dr. Gatot Supangkat (kepala LP3M Universitas Muhammadiyah Yogyakarta), dan Fandom Indonesia yang telah menjadi mitra yang sangat kooperatif. Partisipasi peserta yang sangat baik berkontribusi besar dalam pelaksanaan program ini.

\section{DAFTAR PUSTAKA}

Potter, W. J dalam William F. E (ed.). (2009). $21^{\text {st }}$ Century Communication A Reference Handbook, Volume 2. Thousand Oaks, Californi : SAGE Publications, Inc.

Potter, James (2008). Media Literacy 4th edition. Thousand Oaks: Sage Publications Inc.

Gumilar, G; Adiprasetio, J, dan Maharani, N . (2017). Literasi Media: Cerdas Menggunakan Media Sosial dalam Menanggulangi Berita Palsu (Hoax) oleh Siswa SMA, dalam Jurnal Pengabdian Kepada Masyarakat Vol. 1, No. 1, Februari 2017: 35 - 40 